\title{
TERMINOLOGIA E LEXICOGRAFIA
}

\author{
Marla Tereza Camargo Biderman
}

RESUMO: O léxico se relaclona com a cognição da realidade e com o processo de nomeação que se cristaliza em palavras e termos. $O$ universo conceptual de uma lingua pode ser descrito como um sistema ordenado e estruturado de categorlas. As terminologias cientiflcas são sistemas classificatórios baseados em modelos cientificos e orlundos da estruturação do conhecimento em modelos conceptuals por melo dos quais se organiza cada uma das clênclas. Embora Lexicografia e Terminologia tenham muitas afinidades, existem diferenças entre ambas que precisam ser explicitadas. Na Lexicografia podem ser identiflcadas unidades léxicas multo heterogêneas, ao passo que na Terminologia encontramos unidades léxicas relativamente homogêneas. O repertório lexical da Lexicografla náo se restringe ao universo referenclal, enquanto a Terminologia é centrada no universo referencial. Constitul metodologia bảsica da Terminologia a elaboração de mapas conceptuais de cada área do conhecimento para subsidiar a identificação dos termos, bem como a elaboração de definiçōes desses mesmos termos. Um mapa conceptual se estrutura pelo fato de os conceitos se interrelacionarem lógica e ontologicamente. Por outro lado, Lexicografia e Terminologia têm como pe'dra de toque de sua práxis a identificação das unidades léxicas (palavras e termos) e visam à elaboração de dicionárlos. Ademals, ambas se baselam numa teoria lexical; de fato, palavras e termos se submetem às mesmas regras de formação de palavras da língua. Contudo, em Terminologia é mais freqüente o uso de formantes greco-latinos e a presença de unidades fraseológicas.

Universidade Estadual Paulista (UNESP), Brasil.

TRADTERM, 7, 2001, p. 153-181 
UNITERMOS: Terminologia; Lexicografia; categorias cognitivas; elaboração de dicionários; unidades lexicais; unidades fraseológicas.

ABSTRACT: The lexicon of a language is related to the cognition of reality and with the 'naming' process, as fixated in words and terms. The conceptual universe of a language can be described as an organised and structured system of categories. Scientific terminologies are classification systems based on scientific models originated from the structuring of knowledge in the conceptual models through which every science is organised. In spite of the many similarities between Lexicography and Terminology, there are some differences that need clarification. In Lexicology, very heterogeneous lexical units are identified, while in Terminology relatively homogeneous lexical units are found. In Lexicography the lexical stock is not restricted to the referential level, while in Terminology it is centred on the referential level. It is commonplace in the methodology of Terminology to elaborate conceptual maps of every field of knowledge as an aid for term identification and for the elaboration of their definitions. Conceptual maps are structured because concepts are logically and ontologically related to each other. However, the touchstone of the lexicographical and terminological praxis is the identification of lexical units (words and terms), as well as the objective of producing dictionaries. Besides, both sciences are based on a lexical theory; to be sure, words and terms are conditioned by the same word formation rules in a language. However, the use of Greco-Latin formants and the occurrence of multi-word units are more frequent in Terminology.

KEYWORDS: Terminology, Lexicography, cognitive categories, dictionary production, lexical units, multi-word units. 
A) Pressupostos teóricos

\section{O processo cognitivo, a categorização e a geração do léxico I.1 O léxico se relaciona com a cognição da realidade e com o processo de nomeação.}

O léxico de uma lingua natural constitui uma forma de registrar o conhecimento do universo.

O conhecimento humano se forma a partir da percepção do meio ambiente em que estamos inseridos e com o qual estamos interagindo. A percepção através dos sentidos e de outros recursos neurolingüísticos leva-nos à conceptualização do real. Essa conceptualização se consubstancia numa representação lingüística - num simbolo ou signo verbal - que é a etapa final do processo cognitivo.

Ora, esse complexo mecanismo mental começa a se formar desde que o ser humano nasce e vai-se consolidando pouco a pouco. Em torno de 2 anos a criança aprende que cada coisa tem um nome. Nessa idade a criança se torna consciente dos simbolos e da necessidade deles (Vygotsky, 1977, p.26). É então que a criança começa a constituir seu mundo de objetos, aprendendo a conhecê-los por meio dos nomes que os designam. O nome que designa o referente é um signo lingüistico; esse simbolo verbal representa papel importante na formação do conceito. Por outro lado, convém lembrar que:

Um conceito não é uma formação isolada, fossilizada, imutável mas uma parte ativa do processo intelectual, engajado constantemente em servir à comunicação, ao entendimento e à solução de problemas. (Vygotsky, 1977, p.53)

De fato, os conceitos são dinâmicos e podem ser continuamente reformulados; por outro lado, é certo que a maioria das palavras designam campos de conceitos em vez de objetos físicos ou culturais específicos. Assim, nosso conhecimento do mundo pode ser continuamente revisto e reformulado e as palavras/termos que os referem podem mudar 
não apenas em sua face de significante, mas também em sua face de significado.

O processo cognitivo é essencial na constituição do léxico individual e/ou comunitário. E a palavra/termo dele resultante exerce uma função generalizante porque elimina a necessidade da representação.

\section{I.2 O processo de categorização que resulta da conceptuali- zação da realidade e da nomeação do universo, funda- menta-se num mecanismo mental muito abstrato.}

O mundo real é muito variado e multiforme. O processo de categorização permite-nos simplificar a infinitude da realidade tal como ela se apresenta a nossos sentidos e nos possibilita a conceptualização dessa realidade. A rigor, a categorização é um mecanismo de organização mental da informação, e os conceitos que daí resultam são modos de ordenar ou de tratar os dados sensoriais.

Ora, a categorização supōe a capacidade de generalização. Através do processo de generalização, agrupamos as entidades percebidas no universo (os referentes) de acordo com as semelhanças que possuem entre si; ao mesmo tempo discriminamos os referentes uns dos outros segundo suas diferenças especificas. Se não fosse assim, seria impossivel apreendermos a realidade e ela nos pareceria caótica. A esse processo de discriminação e de generalização segue-se um processo de classificação que se traduz em categorias cognitivas, ou conceitos mentais, que armazenamos em nosso cérebro e que poderia ser considerado como nosso "léxico mental". Por conseguinte, as palavras constituem aquilo que seria o "dicionário" de uma língua natural. Mais ainda: a categorização subjaz à semântica e ao vocabulário de uma língua natural. Pode-se considerar a formação de conceitos como o processo cognitivo primário e a nomeação (designação) como o processo cognitivo secundário.

Pelo mecanismo acima descrito a espécie humana desenvolveu a capacidade de associar palavras a conceitos. Lembremos, nesta altura, o triângulo semiótico, que muito bem explicita este modelo teórico. 
palavra

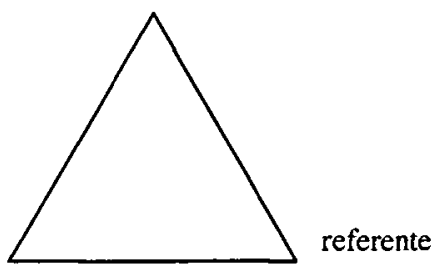

termo

\section{I.3 A nomeação da realidade pode ser considerada como a etapa primeira do nosso percurso cientifico no conheci- mento do universo.}

Foi esse processo de nomeação que gerou o léxico das línguas naturais. A geração do léxico se processou e se processa através de atos sucessivos de cognição da realidade e de categorização da experiência, cristalizada em signos lingüisticos: as palavras e os termos.

Vale a pena enfatizar que os conceitos são modos de ordenar os dados sensoriais da experiência. Através de um processo criativo de organizaçāo cognoscitiva desses dados, surgiram as categorizações lingüisticas expressas em sistemas classificatórios: os léxicos das linguas naturais. Assim, podemos afirmar que o homem desenvolveu uma estratégia engenhosa ao associar palavras/termos a conceitos, que simbolizam os referentes. Os símbolos, ou signos lingüisticos, por conseguinte, se reportam ao universo referencial. Numa etapa posterior, à medída que o conhecimento humano avançava e se sofisticava, foram surgindo os sistemas mais complexos: as terminologias cientificas.

Em suma, o universo conceptual de uma lingua natural pode ser descrito como um sistema ordenado e estruturado de categorias léxico-gramaticais. As palavras e os termos são instrumentos abstratos através dos quais o homem interage cognitivamente com o seu meio.

Portanto, do que aqui ficou dito, o processo de designação é basicamente o mesmo, quer se trate do conhecimento empírico e vulgar do mundo, quer se trate do conhecimento cientifico. De 
fato, em sua essência, o saber empírico não difere do saber científico, pois ambos se dão por meio da categorização e da nomeação subseqüente.

Por outro lado, o léxico de uma língua natural pode ser identificado com o patrimônio vocabular de uma dada comunidade lingüistica ao longo de sua história, acervo esse que é transmitido por essa comunidade de uma geração à geração seguinte.

A transmissão do conhecimento faz-se através do aprendizado empírico no que concerne o vocabulário geral da língua e do aprendizado/treinamento científico no que concerne as terminologias cientificas.

\section{I.4 As terminologias técnico-cientificas.}

O léxico básico das línguas naturais configura o repertório dos simbolos verbais categorizados numa etapa primitiva de cognição da realidade. À medida que as comunidades humanas desenvolveram progressivamente seu conhecimento da realidade, foram sendo criadas as técnicas e as ciências. As sociedades que atingiram esse estágio de civilização, precisaram ampliar sempre mais seu repertório de signos lexicais para designar as criações e os conceitos novos. Em virtude do progresso tècnico e cientifico, da rapidez das mudanças sociais, da integração progressiva das culturas e dos povos, bem como da atuação dos meios de comunicação de massa e das telecomunicações, os léxicos das sociedades mais avançadas estāo crescendo exponencialmente. As designações dos referentes criados pelas técnicas e pelas ciências geraram e geram as terminologias técnico-cientificas. Essas terminologias são sistemas classificatórios engendrados segundo modelos científicos.

Cada comunidade humana que forja o seu instrumental lingüístico para designar conceitos novos, utiliza o modelo léxicocategorial herdado pela lingua e pela cultura de seu grupo social. Assim, os termos técnico-científicos são gerados com base na lógica da lingua em questão, segundo os padrões léxico-gramaticais nela existentes. Excetuam-se os empréstimos lingüisticos, muito freqüentes no mundo contemporâneo, sobretudo anglicis- 
mos, que se estāo propagando por todas as linguas em virtude do papel hegemônico exercido pelos Estados Unidos na contemporaneidade.

Em suma: o patrimônio lexical que as línguas estão constituindo documenta a acumulação do conhecimento humano na contemporaneidade.

As terminologias científicas são sistemas classificatórios baseados em modelos científicos, oriundos da estruturação do conhecimento em modelos conceptuais por meio dos quais se organiza cada uma das ciências. Seguindo Cabré (1993, p.99), que reelaborou idéias de Sager, podemos afirmar também que as terminologias constituem conjuntos imbricados e interrelacionados que dividem o espaço multidimensional do conhecimento em muitos eixos de intersecção. Por outro lado, esses conjuntos se interseccionam com subconjuntos do léxico geral, caracterizados por uma temática, pelos usuários e pelas situações de comunicação. É por isso que ocorre a superposição de termos/conceitos que fazem parte de mais de um domínio do conhecimento.

\section{Diferenças entre Terminologia e Lexicografia II.1 A Lexicografía é a ciência dos dicionários}

O dicionário de língua faz uma descrição do vocabulário de um determinado idioma, dos signos lexicais que referem os conceitos elaborados e cristalizados na cultura. Um dicionário é constituído de entradas lexicais, ou lemas, que ora se reportam a um vocábulo da lingua, ora a um referente do universo extra-lingüistico. A lista total desses lemas constitui a nomenclatura do dicionário, a sua macro-estrutura. Quanto ao verbete, essa microestrutura tem como eixos básicos a definição da palavra em epigrafe e a ilustração contextual desse mesmo vocábulo, quer através de abonações por contextos realizados na lingua escrita ou oral, quer através de exemplos. Os significados e usos referidos são aqueles já registrados e documentados em contextos realizados, e não valores semânticos possiveis, eventualmente atribuiveis aos lexemas da lingua. No dicionário de lingua o verbete é completado com informações sobre registros sociolingüísticos

TraDTerm, 7, 2001, p. 153-181 
do uso da palavra e com remissões a outras unidades do léxico relacionadas com este lema por meio de redes semântico-lexicais. Esse tipo de informação não existe em dicionários especializados de um dominio do conhecimento.

Por sua vez, a Terminologia se ocupa de subconjuntos do léxico de uma língua, a saber, cada área especifica do conhecimento humano. Esses subconjuntos lexicais que constituem o objeto dessa ciêncla reportam-se ao universo referencial. Assim, a Terminologia pressupõe uma teoria da referência, ou seja, uma correlação entre a estrutura geral do conhecimento e o código lingüistico correspondente.

Podemos conceber o universo cognoscivel como um hiperespaço contínuo que recortamos em classes de objetos (ou referentes) através de processos de classificação, de acordo com suas caracteristicas distintivas e com um modelo conceptual engendrado para cada dominio cognitivo.

Como o registro e a transmissão do conhecimento usa o instrumento discreto da língua, o vocabulário técnico-científico deve modelar-se pelos padrōes existentes no sistema lingüistico como melo de abordagem aproximativa desse mesmo conhecimento. Por outro lado, dependendo do enfoque peculiar de uma dada área do conhecimento, um determinado referente pode ser percebido e categorizado diversamente, em função do seu uso em cada domínio cientifico, ou da sua correlação com outros itens de cada subespaço conceptual.

No espaço contínuo do conhecimento, a função referencial da linguagem mapela um repertório discreto e enumerável de símbolos - o léxico. Desta maneira, todo conhecimento do universo é transferido para o léxico em virtude da relação que se estabelece entre cada um dos itens lexicais discretos e o espaço referencial designado. Esses símbolos - signos lingüísticos - não são itens do conhecimento propriamente dito; são-no apenas no sentido de que só podemos manipular o conhecimento abstrato através dessas formas lingüisticas, que somos capazes de memorizar e com que podemos operar. Esses signos são, pois, recursos estratégicos através dos quals podemos referir-nos ao conhecimento do universo.

$O$ uso de um dado termo específico em uma disciplina pressupõe o conhecimento da estruturação desse espaço concep-

TRADTERM, 7, 2001, p. 153-181 
tual e do papel desse termo nesse sistema estruturado de conceitos.

É relativamente simples atribuir uma dada forma - um significante - a um item lexical; é dificil, porém, especificar os limites do conceito ao qual ele se refere. A despeito da norma social que atua na lingua, os individuos podem interpretar os conceitos diversamente segundo sua conceptualização da realidade. Conseqüentemente, os usuários da lingua podem atribuir ao mesmo item lexical uma referência que contenha discriminações sutis em relação ao conhecimento do mesmo espaço cognitivo, isto é, podem usar o mesmo termo para referir pontos não coincidentes no universo cognoscivel. Eis por que é desejável uma certa normalização terminológica para garantir uma relativa univocidade do significado e do uso do termo cientifico. $\mathbf{E}$ mesmo desejável obter o consenso de especialistas sobre o sentido e a delimitação de um termo científico num dado dominio. Para sanar essa dificuldade pode-se propor e até impor a uniformidade de uso do termo, fixando oficialmente um padrão terminológico. Mesmo sendo dificil atingir a total uniformidade de referência, um razoável consenso pode ser obtido. Essa é uma diferença nitida entre os termos dos dominios cientificos e as palavras do léxico comum.

\section{II.2 Guadro contrastivo entre a Terminologia e a Lexicogra- fia. Lexicografia Terminologia}

\begin{tabular}{|l|l|}
\hline \multicolumn{1}{|c|}{ Lexicografia } & \multicolumn{1}{|c|}{ Terminologia } \\
\hline $\begin{array}{l}\text { unidades léxicas muito heterogêneas (quanto à } \\
\text { forma e à função): palavras de significação e } \\
\text { palavras instrumentais }\end{array}$ & $\begin{array}{l}\text { unidades léxicas relativamente homogêneas: } \\
\text { substantivos (maioria), adjetivos, verbos e alguns } \\
\text { advérbios }\end{array}$ \\
\hline mais abrangente & circunscrita a um domínio \\
\hline não se restringe ao universo referencial & centrada no universo referencial \\
\hline $\begin{array}{l}\text { relaciona-se com todas as funções da linguagem: } \\
\text { função referencial, f. emotiva, f. conativa, f. fática, } \\
\text { f.poética, f. metalingurstica }\end{array}$ & relaciona-se com a função referencial \\
\hline
\end{tabular}

Vê-se na tabela que a Lexicografia é mais abrangente que a Terminologia no que concerne às unidades léxicas, pois, no léxico geral, as unidades são muito heterogêneos, seja quanto à forma, seja quanto à função. Inversamente, na Terminologia, as unidades lingüisticas são relativamente homogêneas. 
A Lexicografia não se restringe ao universo referencial em que está centrada a Terminologia. Como a Lexicografia busca descrever o léxico geral da lingua, ela se relaciona com todas as outras funções da linguagem. O léxico geral cobre o contexto da comunícação dialógica bem como o universo referencial, passivel de cognição pelo sujeito humano. Por isso é mais abrangente e heterogêneo do que um léxico especializado que seria objeto de uma descrição terminológica. De fato, o léxico geral engloba não só as palavras que denotam o universo referencial, mas também as palavras que articulam a comunicação entre os homens e, assim, compreende todas as unidades que se reportam às várias funções da linguagem: a função emotiva ou expressiva (centrada no emissor), a função conativa (centrada no receptor), a função fática (centrada na comunicação) e os instrumentos gramaticais de articulação do discurso. Distingue-se, pois, radicalmente, dos léxicos especializados, que se reportam apenas à função referencial e, portanto, dizem respeito à descrição e à representação da realidade e do universo cognoscivel.

Contudo, as duas ciēncias se tocam, fazem intersecção no dominio do universo referencial. Uma parcela considerável do repertório do léxico geral é constituida de termos que se vulgarizam e até se banalizam. No mundo contemporâneo, marcado por um fortíssimo prestigio das ciências, em que as comunicações se tornaram um fenômeno universal, a mídia divulga e vulgariza rapidamente o conhecimento científico. Além disso, a busca da informação, fenômeno generalizado dentro da sociedade contemporânea, já que a nossa é uma sociedade da informação, faz com que a circulação do conhecimento, criado pelos cientistas e pelos técnicos, chegue rapidamente ao cidadão comum. Assim, o vocabulário especializado que acompanha o saber científico penetra incessantemente no léxico geral. $\dot{E}$ claro que, muitas vezes, esses termos não se vulgarizam, mantendo todo o rigor de sua denotação de origem. Entretanto, podem adquirir denotações e mesmo conotações distintas das originais; gera-se assim o fenômeno da polissemia, a partir de termos científicos originalmente monossêmicos. Desta forma, a sinonímia, fenômeno típico da significação do vocabulário geral da língua, se verifica igualmente nas terminologias. 
Por outro lado, tanto a Lexicografia como a Terminologia visam à elaboração de dicionários. Essa meta compreende duas etapas principais:

a) a organização da macroestrutura;

b) o estabelecimento dos modelos da microestrutura.

A etapa a) supõe um trabalho prévio: a identificação das unidades léxicas nas realizações discursivas, que comporão a macroestrutura do dicionário. Essa tarefa implica no estabelecimento do conceito de unidade léxica e/ou terminológica. Dai parte a tarefa pragmática de coletar os lemas ou termos para comporem a nomenclatura do dicionário. Implica também o estabelecimento de um corpus representativo, quer da lingua em geral (Lexicografia), quer do domínio terminológico estudado (Terminologia).

No que concerne às fontes de dados (corpus) para a Terminologia, devemos servir-nos da documentação especializada, sobretudo escrita. Só marginalmente, a lingua falada constitui fonte de coleta de termos, diversamente do que ocorre com a Lexicografia.

Outra peculiaridade da Terminologia face à Lexicografia advẻm de um de seus objetivos, a saber: a normalização/padronização, que interfere na configuração e estabelecimento dos conceitos.

Isso posto, vejamos quais etapas do trabalho terminológico precedem à elaboração de um dicionário de um dominio especializado:

a) organização da estrutura nocional do dominio científico $\Rightarrow$ elaboração do mapa conceptual desse dominio;

b) mapa conceptual $\Rightarrow$ formado de conceitos interrelacionados lógica e ontologicamente.

O conjunto desses conceitos forma o sistema conceptual daquele domínio científico. Por outro lado, a cada conceito corresponde um termo. Se um conceito corresponder a mais de 
um termo, a saber: conceito A corresponde ao termol, ao termo2 e ao termo3, será preciso proceder à seleção de um termo canônico que será a entrada - lema - do dicionário terminológico em questão. Conseqüentemente, será preciso consignar as variantes (sinônimos, parassinônimos) no dicionário, adicionando-se as devidas remissões.

De fato, a monorreferencialidade é apenas um desideratum e não um fenômeno usual, ocorrendo, muitas vezes, que um conceito seja designado por mais de um termo, como ocorre geralmente com o léxico comum.

Quanto ao aspecto organizacional, identificamos algumas semelhanças dos léxicos especializados com o léxico comum. As palavras estruturam-se no sistema semântico da lingua gerando redes semânticas muito complexas. De fato, na mente do falante, as palavras não estāo isoladas, mas integram conjuntos ou campos semânticos ordenados e estruturados. Caso contrário, seria impossivel recuperar uma palavra no acervo mental do léxico. Essa estruturação guarda um certo paralelismo com o sistema nocional de um dado domínio científico.

\section{II.4}

Para coletar os termos de um dominio terminológico é preciso primeiro definir claramente o que é um conceito. Um conceito é uma representação mental abstrata composta por um conjunto de traços comuns e essenciais a um grupo de entidades (objetos ou idéias) que se obtém pela subtração das características individuais dessas entidades. Pode-se afirmar também que um conceito pode ser concebido como uma representação mental da realidade, ou como uma unidade do conhecimento que faz parte de um sistema nocional estruturado. Esses parâmetros guiarão o terminólogo na identificação dos termos (conceitos) do domínio científico em que está trabalhando.

A etapa seguinte seria a da elaboração das definições dos termos como em qualquer dicionário de lingua.

A definição deve descrever as características de um conceito, integrando-o numa estrutura conceptual de um dado domínio 
do conhecimento. Como os conceitos são representações mentais, para definir um conceito é necessário selecionar:

1) suas caracteristicas intrinsecas ou inerentes;

2) suas caracteristicas extrinsecas ou a relação do objeto com outros objetos: origem, função, relação (espacial, temporal, causal).

Finalmente, no que concerne à descrição do léxico, lembrese que os dicionários buscam exatamente descrever e organizar o léxico geral e os léxicos especializados com relação a:

1) léxico geral $\Rightarrow$ tarefa da Lexicologia/Lexicografia

2) léxicos especializados $\Rightarrow$ tarefa da Terminologia/Terminografia

Portanto, a elaboração de dicionários é uma finalidade tanto da Lexicografia como da Terminologia.

Outra questão importante relativa à elaboração de dicionários: como deveriam ser organizadas as unidades - as entradas de dicionário - nestas obras? A prática corrente e tradicional é a ordem alfabética. Entretanto, o sistema alfabético obscurece, subverte a estrutura semântico-conceptual, porque não evidencia a estruturação do léxico. $O$ ideal seriam os dicionários analógicos/ideológicos que distribuem as unidades do léxico geral e/ou especializado a partir de campos semânticos e/ou áreas conceptuais.

Também se poderia sobrepor a estrutura conceptual/semântica à alfabética através de remissões e referências cruzadas, que reestabelecem os vinculos das redes semânticas e dos mapas conceptuais. O modelo onomasiológico se baseia na organização analógica/ideológica, organização que permite recuperar a estrutura do léxico.

\section{B) Questões práticas}

Tratarei de algumas questões práticas com respeito à Terminologia è̀ Lexicografia. 


\section{A identificação da unidade léxica}

Não vou discutir a questão da identificação das unidades simples do léxico; examinarei apenas a problemática das unidades complexas, as quais constituem a grande maioria dos termos das linguagens de especialidade. Relativamente ao problema da identificação das unidades complexas, o problema é similar no que concerne ao léxico geral e aos léxicos especializados. No caso do léxico geral, porém, um fator determinante para a lexicalização de um sintagma discursivo - que o torna uma unidade complexa fundamenta-se na freqūència do uso. $O$ sentimento dos falantes em relação ao término de um processo de lexicalização é fundamental. No que concerne aos léxicos especializados, o parâmetro fundamental é a estruturação do espaço conceptual no interior do dominio científico em apreço e a referência no interior desse espaço.

No tratamento de corpora informatizados com vistas à elaboração de dicionários, é problemática a identificação das unidades complexas do léxico. Há seqüências - sintagmas discursivos - que desencadeiam no falante a intuição de frase estereotipada, fixa. Como muitos lingüistas já notaram, tais seqüencias, ou combinatórias, mostram uma fixidez tipica de lexemas cristalizados no léxico. Entretanto, não é fácil separar os sintagmas cristalizados no léxico de formas intuitivamente freqüentes, ou seja, distinguir as combinatórias lexicalizadas daquelas em vias de lexicalização, ou simplesmente discursivas.

Aliás, existe no interior do léxico um repertório onde se exerce a livre escolha do falante e ele pode selecionar livremente as unidades lexicais para seu discurso; contudo, existe um outro repertório onde o critério imperante é o do princípio idiomático. Nessa segunda hipótese, o falante poderá extrair do patrimônio lexical da lingua, não mais palavras isoladas, mas um grande número de combinatórias lexicais pré-construídas ou semi-pré-construídas, combinatórias estas que se transformaram em verdadeiras rotinas estocadas na memória. (Bacelar, 1998, p.184) 
Vou transcrever a seguir alguns contextos, extraídos de um corpus de 11 milhões de ocorrências vocabulares ${ }^{1}$ para evidenciar a problemática das unidades complexas do léxico, tanto aquelas que deveriam ser enquadradas no lemário de um dicionário de lingua, quanto aquelas que seriam preferencialmente de um domínio especializado. $\mathrm{E}$ antes de passar aos exemplos, cito uma estudiosa italiana, que examinou criteriosamente esse problema.

Ornella Corazzari (1992, p.5) afirma:

De um ponto de vista sintático as unidades fraseológicas têm graus diferentes de cristalização, isto é, elas resistem a algumas manipulaçōes morfossintáticas (transformações, inserção de modificadores, flexão) e comutações léxicas que são geralmente possiveis com construções equivalentes comuns.

E conclui com esta definição:

unidades fraseológicas são seqüências de palavras que têm uma coesão interna do ponto de vista semântico e que possuem propriedades morfossintáticas especificas.

Extrai do nosso corpus uma série de contextos com o adjetivo verde em que se pode identificar a presença de sintagmas discursivos, de lexias complexas do léxico geral e de unidades terminológicas de dominios técnico-científicos. ${ }^{2}$

1 Cf. base textual da Unesp de 80 milhōes, Centro de Lexicografia, Campus de Araraquara.

2 Estão indicados neste exemplário o tipo de literatura ou gênero e o nome da obra de que foi extraído o contexto. Assim: $L R=$ literatura romanesca (romances e contos); $\mathrm{LT}=$ literatura técnica e científica; $\mathrm{L}=$ literatura jornalistica (jornais e revistas). Quando estiver indicado Veja é o subcorpus especial da revista Veja (todas os números de 1992 a 1995).

TradTerm, 7, 2001, p. 153-181 
Vejamos primeiro combinatórias do adjetivo verde com o substantivo luz, em que o sintagma resultante pode ser identificado como uma lexia complexa do léxico comum.

\section{luz verde}

1) Nos aeroportos brasileiros, a força da propina abre portas, acende luz verde e libera bagagens (Veja, 5/7/95)

2) E a ministra Dorothéa, que já estava em contato com montadoras e metalúrgicos, recebeu luz verde para negociar o acordo. (Veja, 8/2/95)

3) Ao dar luz verde para a atividade sexual dos craques $\mathrm{e}$ luz vermelha para as esposas os acompanharem aos Estados Unidos, Parreira encaminhou a questão para um ponto delicado. (Veja, 8/5/94)

4) "Eles me ofereceram a luz verde por 2.000 dólares", contou à Veja na semana passada um conhecido empresário paulista. A luz verde é um sinal eletrônico que libera o passageiro da inspeção na alfândega. (Veja, 4/7/93)

Notamos nestes contextos que a seqüência luz verde é usada como uma unidade do léxico português e até mesmo com um valor metafórico, como podemos perceber nos quatro enunciados. Na última seqüência, o jornalista, autor do texto, explicita a metáfora na segunda frase de seu enunciado. Entretanto, essa lexia complexa poderia ser uma unidade terminológica, por exemplo, em textos ou em uma situação de comunicação do domínio de Transportes, ou do Urbanismo.

Outro exemplo distinto - esse de uma combinatória que gerou uma unidade complexa de natureza idiomática - é o de:

\section{inferno verde}

1) Na travessla porém, em pleno coração do inferno verde, fol prostrado a tíros e roubado a mando do antigo patrão, a quem tivera a honradez de não flcar devendo (LR: Dentro da Vida). 
2) Paraíso perdido, eldorado... inferno verde... As imagens extremadas historicamente construídas sobre a Amazônia se reproduzem hoje com novas feições e intensidade. (LT: $A$ Amazônia no espaço brasileiro).

3) $[. .$.$] muitas inteligências de escol, dentro e fora de nos-$ sas fronteiras, se debruçaram com beneditina paciência sobre a realidade do inferno verde. Euclides, Rangel, Gastāo Cruls, Raimundo Morais, Viana Moog, Artur César Ferreira Reis, para citar alguns poucos brasileiros [...] (LJ: Correio do Povo, 28/12/67).

Vamos considerar agora o caso de uma unidade fraseológica que pode integrar tanto o léxico geral como o de uma área de especialidade.

\section{área verde / áreas verdes}

1) E para descansar, os apartamentos do Hotel Transamérica são confortáveis e espaçosos, com infra-estrutura completa de serviços e a maior área verde que um hotel oferece em São Paulo (publicidade relativa ao Hotel Transamérica, extraido do subcorpus de Propaganda).

2) Em que medida o Parque Ecológico do Tietê beneficia a população de São Paulo? Sem dúvida, eleva o percentual de área verde por habitante, auxilia na oxigenação da área metropolitana e, em si mesma, é uma iniciativa das mais louváveis (LT: O que é lazer).

3) Surgiram, então, as primeiras conseqüências: diminuição das áreas verdes que lhe [ao homem] traziam conforto e prazer, poluiçāo de rios com efeitos desastrosos à fauna e à flora, alteração da qualidade do ar respirado nas grandes cidades [...] (LT: Ecologia).

4) Em algumas quadras os moradores pedem asfalto, calçadas, áreas verdes, opções de lazer e etc. (WJ: Correio Brasiliense, 1979).

5) As áreas verdes são muito importantes em qualquer das grandes cidades marroquinas (W: revista Claudia). 
Estes contextos mostram que, no interior do domínio Ecologia, Meio Ambiente, a unidade fraseológica área verde funciona como um termo. Nos contextos de linguagem jornalistica, temse o fenômeno tipico da vulgarização e até banalização de um termo técnico da Ecologia. É verdade que, sobretudo nessa área técnica, grande número de termos foram extraídos de domínios que se interseccionam com o Meio Ambiente, ou de palavras do vocabulário comum. Na verdade, a Ecologia é uma ciência heteróclita, multidisciplinar, que se intersecciona com um grande número de outros dominios do conhecimento.

Em decorrência da associação constante do <verde> com o Meio Ambiente, o adjetivo verde acabou por adquirir um significado metafórico, translato, querendo significar <que diz respeito ao meio ambiente, à natureza>. Donde: partido verde, deputado verde, bancada verde, causa verde e até: revolução verde.

1) [...] o engenheiro agrônomo americano Norman Borlaug, considerado o pai da "Revolução Verde" e ganhador do Prêmio Nobel da Paz de 1970 pelo desenvolvimento de novas técnicas agricolas nos países do Terceiro Mundo. (Veja. $31 / 5 / 95)$

2) Essa segunda Revolução Verde gerará frutos e hortaliças resistentes a pragas cujo cultivo dispensará o uso de defensivos quimicos. (Veja, 20/10/93)

No quadro em que se estabeleceu o contraste entre a Terminologia e a Lexicografia (II.2.), vimos que as unidades do léxico geral, e portanto aquelas que concernem à Lexicografia, são muito heterogêneas. Também se disse que a Lexicografia se relaciona com todas as funções da linguagem e não apenas com a função referencial, caso da Terminologia. Para ilustrar esse fato vejamos unidades complexas do léxico comum formadas com a palavra vida e extraidas também do mesmo corpus da Unesp já referido. Num total de 11 milhōes de ocorrências foram registradas 41 unidades complexas diferentes tais como: boa vida lou boa-vida], caso de vida e morte, ciclo de vida, coisas da vida, custo 
de vida, embalagem longa-vida, esperança de vida lexpectativa de vida], estilo de vida, feliz da vida (adj.), filosofia de vida, formas de vida, ideal de vida, meio de vida, modo de vida, padrão de vida, qualidade de vida, risco de vida, ritmo de vida, seguro de vida, sem vida (adj.), vida adulta, vida afetiva, vida amorosa, vida conjugal, vida de cachorro [vida de cão], vida de casado, vida em comum, vida em familia, vida eterna, vida futura, vida interior, vida moderna, vida normal, vida noturna, vida nova, vida pessoal, vida profissional, vida real, vida sedentária, vida sexual, vida útil. Nesse extenso exemplário verificamos que há sintagmas cristalizados no léxico (ciclo de vida, embalagem longa-vida, qualidade de vida, seguro de vida, vida de cachorro); outros, que estão em vias de lexicalização (boa vida, meio de vida, vida profissional, vida útil); e outras combinatórias que são muito freqüentes mas seriam ainda discursivas e não lexicalizadas (estilo de vida, feliz da vida, sem vida (?), vida amorosa, vida em família, vida eterna, vida noturna, etc.). Talvez a maior parte desses sintagmas sejam simplesmente freqüentes, já que em vários deles não identificamos um referente diferente. Seja como for, a linha divisória entre uns e outros é muito tênue. Conseqüentemente, na organização do lemário do dicionário, tais unidades teriam um tratamento diverso. A primeira categoria entraria como unidade da macroestrutura e as demais entrariam como subentradas do lema vida.

Resumindo: há seqüências fraseológicas que podem ou não ser unidades lexicais da língua, ou ser unidades terminológicas de um dado domínio do conhecimento. Em ambos os casos é preciso distinguir os sintagmas discursivos das unidades lexicalizadas. Se concluirmos que se trata de uma unidade fraseológica, os procedimentos para identificar a unidade do léxico geral da lingua diferem bastante daqueles que dizem respeito à identificação de um termo de uma lingua de especialidade. Neste último caso, será imprescindivel levar em consideração a especificidade temática, isto é, o dominio científico com que se está trabalhando. Assim, selecionadas as unidades que aparecem nos textos, para identificá-las ou não como termos, é necessário verificar se elas são pertinentes àquela linguagem de especialidade - a do dominio científico em questão. Nos contextos que citamos acima (de combinatórias com verde), seria o caso de área verde (no âmbito de Ecologia), mas não de inferno verde. Aliás, o fato de 
termos encontrado o termo área verde num livro sobre Ecologia constitui um indice comprobatório para o teste, pois nesse âmbito, área verde refere um conceito da estrutura conceptual do Meio Ambiente. Convém lembrar ainda que critérios formais não são suficientes para identificar uma unidade fraseológica de um dominio terminológico. Precisamos considerar também critérios semânticos e pragmáticos. $\mathrm{E}$ enfim, será preciso levar em consideração a pertinência do conceito referido pela unidade fraseológica na estruturação do espaço conceptual da área do conhecimento em questão.

\section{Formação de palavras}

Para formar palavras novas, as regras de formaçāo de palauras são as mesmas para os termos e para os vocábulos do léxico comum. Entretanto, em Terminologia, é mais freqüente o uso de formantes greco-latinos e a presença de unidades fraseológicas.

Assim, para a lingua portuguesa, termos e palavras do léxico comum são gerados pelos processos seguintes:

1) derlvação:

a) prefixação,

b) sufixação;

2) composição;

3) conversão.

Na verdade, esta última categoria, que já é rara no léxico comum, torna-se rarissima numa lingua de especialidade. Dentre as demais, a derivação é certamente o processo mais corrente. Não será possivel tratar de todos esses processos, razão por que será dado apenas um exemplo.

A título de ilustração vou comentar alguns exemplos de prefixação com o prefixo micro-.

Quando usados para a criação de termos nas ciências, os prefixos veiculam sentidos especificos. Vejam-se alguns exemplos com o prefixo micro-.

micro- = <pequeno, de dimensões pequenas> 


\section{microondas}

Ondas eletromagnéticas muito curtas, usadas em redes de comunicação de alta capacidade, para a emissão de sinais de rádio de freqüência ultra-alta ou super-alta, que se deslocam à velocidade da luz, em linha reta, transmitindo voz e sinais de dados a altissima velocidade. (Dicionário Enciclopédico de Informática)

\section{microeletrônica}

Arte e tecnologia de projeto, fabricação e utilização de circuitos eletrônicos altamente miniaturizados. (Dicionário Brasileiro de Eletricidade)

\section{microclima}

Variação em escala muito pequena do padrão climático total, geralmente causada por condições fisicas locais como a topografia. Um bolsão de frio é um exemplo de microclima, assim como a sombra sob uma árvore, ou um pequeno lago. Os microclimas têm grande influência sobre nichos ecológicos. (Dicionário de Ecologia e Ciências Ambientais)

\section{microcirurgia}

Procedimento cirürgico realizado por meio de um microscópio cirúrgico que permite o aumento do campo visual operado. (Stedman's Pocket Medical Dictionary) ${ }^{3}$ microbiologia

\section{microbiologia}

(do grego mikros, pequeno; bios, vida; logos, estudo). Biol. Parte da biologia que estuda os micróbios, especialmente os agentes patogènicos. Divide-se em: bacteriologia (bacté-

3 Fol usado aqui um diclonário publicado em inglês e traduzido o verbete para mostrar como nos vocabulários especializados pode-se fazer a transposição de uma língua para outra, visto como os conceitos cientificos são universais, bastando buscar o termo equivalente na lingua de chegada. 
rias), micologia (fungos) e virologia (virus). (Diccionario Terminológico de Biologia) ${ }^{4}$

\section{microgameta}

(do grego mikros, pequeno; gamétes, esposo). Citol. Nome que recebe o elemento sexual masculino (anterozólde ou espermatozóide) por seu pequeno tamanho em relação ao óvulo. (Diccionario Terminológico de Biología) ${ }^{5}$

\section{micropertita}

Variedade de pertita em que os lamelas de albita só são visiveis ao microscópio. Do gr. mikros (pequeno) e pertita. (Dicionário de Mineralogia).

\section{microtom}

Intervalo menor que um semitom. Os quartos de tom foram sistematicamente explorados por A. Haba e outros tchecos, e também tiveram um uso ocasional em contextos mais "ortodoxos", por exemplo, as partes das cordas na música de câmara de Bloch [...] (Diccionario de Música).

Os exemplos de definições de termos acima evidenciam que o uso do prefixo micro- se expande por uma área ampla, embora se tenha dito que ele significa <pequeno, de dimensões pequenas>. Vejamos: em microondas, microgameta, o sentido do prefixo se aplica à base (ondas, gameta). Em microcirurgia, micropertita, o sentido do prefixo se aplica a <o que é visivel ao microscópio>, o que é evidentemente um significado translato, poderiamos dizer, por metonímia. Em microeletrônica, o sentido de <pequeno> está presente na utilização e nos produtos produzidos por esta técnica. Em microclima, trata-se do clima gerado numa área pequena. Em microbiologia, micro- se reporta aos seres estudados pela ciência designada pela base. Em microtom, micro- quer dizer apenas que a unidade de medida musical referida é menor que a unida-

4 Neste caso também fof usado um dicionárło estrangeiro, a saber, um diclonário em espanhol publicado na Argentina.

5 Idem. 
de referida pela base. Esses exemplos mostram como o uso que foi feito do prefixo micro- na criação de termos não se conformou ao modelo, que seria micro- especificando o significado da base. Além disso, micro- pode ainda significar: <um milhāo de vezes menor>. Cf.:

\section{micrograma}

Peso de um milionésimo de grama.

\section{microssegundo}

Intervalo de tempo correspondente à milionésima parte do segundo.

Portanto, para a interpretação correta de um termo, não basta o conhecimento dos conteúdos semânticos da base e do prefixo; faz-se necessária a familiaridade com o dominio de conhecimento especializado e não apenas com o significado dos constituintes do termo, visto que as criaçōes terminológicas muitas vezes falseiam os elementos semânticos presentes, como se viu aqui.

Vale a pena confrontar também alguns resultados obtidos de uma análise feita num subcorpus da base textual da Unesp (6 milhōes de palavras). Embora menor, ele é ainda muito grande e muito variado quanto ao gênero e tipologia discursiva do português brasileiro contemporâneo. Nesse total, contabilizamos 74 ocorrências de palavras derivadas com micro-só na literatura romanesca (romances e contos), a saber:

microscópio, microscópico, microfone, microcosmo, microônibus, microfilmagem, microondas, microexplosōes, microorganismo, microbiano, microbiologia.

Note-se que os vocábulos mais freqũentes foram: microfone $\mathrm{e}$ microscópio.

Na literatura dramática ocorreram 75 formas, mas quase $100 \%$ dessas ocorrências foram da palavra microfone; logo, todas as demais possiveis simplesmente não ocorrem neste tipo de texto. 
Inversamente, na literatura técnico-cientifica houve 422 vocábulos formados com micro-, que foram: todos os vocábulos que ocorreram na literatura romanesca e mais os seguintes:

microcomedores, microcomputador, microscopicamente, microfilia, microtelefone, microfônico, microssomas, microssômico, microregião, microcefalia, micronutriente, microcesária, microeletródio, microbalāo, microftalmia, microvilosidade, microcaracteres, microcitico, microfeixes, microestimulação, microambiente, microprocessador, microinfoormática, microempresa, microcircuito, microrrede, microbiota, microprotalo, microsporângio, microfóssil, microplasma, microjoaninha, microcrustáceo, micronúcleo, microcirculação, microeletrônico, microwatt, micrografia, microclima, microtérmico, microclimático, microcarcinoma, micropontos, microlepidóptero, microcitos, microelemento, microdesvio, microscopia, micro-histiocito, micropaleontologia, microssociedade, micro-história, microbiologicamente, micropausa, micrograma, microfônico.

Não é preciso insistir mais na proeminência deste prefixo e deste processo de formação de termos/palavras nas linguagens de especlalidade diversamente da linguagem geral.

\section{Confronto de verbetes tratados pela Lexicografia e pela Terminologia}

Vamos opor agora verbetes e definiçōes de um dicionário de lingua (Aurélio) e um dicionário terminológico. ${ }^{6}$

6 Os exemplos dos verbetes de Lexicografia foram extraídos da versão 2.0 Dicionário Eletrônico Aurélio.

Obs: não se transcrevem aqui os verbetes inteiros do Dicionário Aurélio, mas apenas a parte que interessa para confronto com o Glossário.

Os exemplos de verbetes de Terminologia foram extraidos do:

Glossário de termos neológicos de Economia

Coord. Ieda Maria Alves.

Citrat-FFLCH/USP Humanitas, São Paulo, 1998. 
$\underline{\text { Aurélio }}$

Emprego (ê) [Dev. de empregar.] S. m.

1. Ato de empregar; aplicação, uso:

2. Cargo, função, ocupação em serviço particular, público, etc.; colocação:

3. Lugar onde se exerce emprego: [Pl.: empregos (ê). Cf. emprego, do v. empregar.]

[...]

\section{Glossário}

Emprego formal S.m.

Emprego que oferece registro em carteira profissional ao trabalhador.

Contexto: [...]

Sin. Trabalho assalariado formal

Cf. economia formal, emprego informal

Emprego informal S.m.

Emprego que nāo oferece registro em carteira profissional ao trabalhador.

Contexto: [...]

Sin. Trabalho informal

Cf. economia informal, emprego formal

Aurélio

Pacto [Do lat. pactu.] S. m.

1. Ajuste, convenção, contrato. [Sin. (bras., N.E., pop.): pauta.]

2. Constituição (3) pela qual se regem certos Estados confederados como, p. ex., a Suiça. [Cf. pato.]

Pacto adjeto. Jur.

1. V. contrato acessório.

Pacto de sangue.

1. Aquele em que os pactuantes dão em si mesmos um corte e fazem, depois, que se lhes misturem os sangues, em penhor do cumprimento do pacto; juramento de sangue. 


\section{Glossário}

Pacto fiscal S.m.

Pacto estabelecido entre governo e setores da sociedade com o objetivo de alterar a forma de financiamento do setor público.

Contexto: [...]

Cf. setor público

\section{Glossário}

\section{Pacto social S.m.}

Pacto estabelecido entre governo e vários setores da sociedade com o objetivo de realizar modificações na politica econômica.

Contexto: [...]

\section{Aurélio}

Rendal [Dev, de render.] S. f.

1. Resultado financeiro de aplicação de capitais ou economias, ou de locação ou arrendamento de bens patrimoniais:

2. Rendimento (3):

3. Gualquer rendimento (3) sujeito a obrigações tributárias:

4. V. receita (1):

5. O total das quantias recebidas, por pessoa ou entidade, em troca de trabalho ou de serviço prestado; receita:

6. Bras., SP. Obsol. Rendimento de um saco de café em coco, de $40 \mathrm{~kg}$, calculado por amostragem. [De cada remessa de sacos ao comprador tiram-se amostras que, reunidas e pesadas, são, a seguir, beneficiadas; se, p. ex., 40 $\mathrm{kg}$ de amostras produzem $22,3 \mathrm{~kg}$ de café beneficiado, o saco remetido renderá $22,3 \mathrm{~kg}$.]

Renda nacional. Econ.

1. Soma de todas as remunerações pagas aos proprietários dos fatores de produção num determinado periodo. [ $\hat{\mathrm{E}}$ igual ao Produto Nacional líquido, menos os impostos indiretos, mais os subsidlos.] 
Renda per capita.

1. Resultado da divisão da renda nacional pelo número de habitantes de um pais, e que é indicador imediato e geral de um processo de desenvolvimento; renda por pessoa.

Renda por pessoa.

\section{Glossário}

Renda bruta S.f.

Rendimento total de um individuo ou entidade, durante um periodo determinado, sem desconto de tributos e contribuiçōes sociais.

Contexto: [...]

Cf. renda líquida

\section{Glossário}

\section{Renda fixa S.f.}

Rendimento cujo valor é estabelecido previamente.

Contexto: [...]

Nota sintagmas expandidos: ativo de renda fixa, fundo de renda fixa, mercado de renda fixa, papel de renda fixa, título de renda fixa

Cf. renda variável

\section{Glossário}

\section{Renda líquida S.f.}

Rendimento de um individuo ou entidade, durante um periodo determinado, descontados tributos e contribuições sociais.

Contexto: $[\ldots]$

Cf. renda bruta

\section{Glossário}

\section{Renda real S.f.}

Rendimento de um individuo ou entidade, durante um periodo determinado, descontadas eventuais taxas de inflação. Contexto: [...]

\section{Cf. taxa de inflação}




\section{Glossário}

\section{Renda variável S.f.}

Rendimento cujo valor, não-estabelecido previamente, varia de acordo com as oscilações do mercado.

Contexto: [...]

Nota sintagmas expandidos: aplicação em renda variável, mercado de renda variável

\section{Cf. renda fixa}

Este pequeno exemplário mostra a diferença entre a definição lexicográfica e a definição terminológica com verbetes extraídos das obras referidas, que definem unidades similares, ou melhor, conceitos/significados de dominios (campos semânticos) muito próximos e que interseccionam. Faz-se aqui referência ao que se disse acima sobre o fato de um dado referente poder ser categorizado diversamente, dependendo do seu uso em cada domínio científico, da sua correlação com outros itens dessa área do conhecimento, bem como de sua intersecção com o léxico geral.

\section{Referências bibliográficas}

BIDERMAN, M.T.C. (2001) Teoria Lingüistica. (Teoria Lexical e Lingüistica Computacional). São Paulo: Martins Fontes.

(1998) Dimensões da palavra. Filologia e Lingua Portuguesa, n. 2. São Paulo: Humanitas/FFLCH/USP, p.81-118.

CABRÉ, M.T. (1993) La terminologia. Teoria, metodologia, aplicaciones. Barcelona: Editorial Antártida/Empúries.

CANO, W.M. (1998) Prefixaçāo no vocabulário técnico-científico. ALFA, v.42 (n.esp.: O estado da arte nas ciências do léxico: lexicologia, lexicografia e terminologia). São Paulo: Edunesp, p.71-91.

CORAZZARI, O. (1992) Phraseological Units, Consiglio Nacionale delle Richerche. Instituto di Linguistica Computazionale. Network of European Reference Corpora (NERC). serial n. 68. Pisa (manuscrito). CUENCA, M. J. e HILFERTY, J. (1999) Introducción a la lingüistica cognitiva. Barcelona: Ariel Lingüística. 
Dicionário Brasileiro de Eletricidade. Rio de Janeiro, ABNT, 1986.

Dicionário de Ecologia e Ciências Ambientais. Trad. Unesp/Melhoramentos, 1998.

Dicionário de Mineralogia. Porto Alegre: Sagra, 1987.

Diccionario de Música. Buenos Aires: Losada, 1990.

Dicionário Enciclopédico de Informática. Rio de Janeiro, São Paulo: Nobel/ Campus, 1986.

Diccionario Terminológico de Biología. Buenos Aires: El Ateneo, 1994.

GROSS, M. (1988) Les limites de la phrase figêe. Langages, $n^{\circ} 90$. Paris, p.7-22.

NASCIMENTO, M.F.B. do \& PEREIRA, L. A. S. (1998) Dicionário de Combinatórias do Português (variedade européia). Alfa, v.42 (n.esp.), p.183-203.

Stedman's Pocket Medical Dictionary. Baltimore: William \& Wilkins, 1987. VYGOTSKY, L.S. (1977) Thought and Language. Cambridge, MS, M.I.T. Press. 
